DOI:10.24193/tras.SI2019.5

Published First Online: 2019/12/21

\section{HUMAN RESOURCE PRACTICES, FAILURE MANAGEMENT APPROACH- ES AND INNOVATIONS IN SERBIAN PUBLIC ADMINISTRATION}

\section{Milenko RADONIĆ \\ Miloš MILOSAVLJEVIĆ}

\author{
Milenko RADONIĆ \\ $\mathrm{PhD}$ candidate, Faculty of Organizational Sciences, \\ University of Belgrade, Belgrade, Serbia \\ Tel.: 00381-11-3950.875 \\ E-mail: radonic.milenko@gmail.com
}

\section{Miloš MILOSAVLJEVIĆ}

Assistant professor, PhD, Faculty of Organizational Sciences, University of Belgrade, Belgrade, Serbia

Tel.: 00381-110-3950.875

E-mail: milos.milosavljevic@fon.bg.ac.rs

\section{Abstract}

This paper responds to a recent call for research on public administration innovations as a necessity for the development of modern governance. In particular, this paper aims to examine the role of high-performing human resource practices in fostering the innovation of public administration. In addition, the study explores the mediating effect of failure management practices on innovativeness. A sample of 618 political appointees and civil servants from Serbian central administration was used to test the aforementioned hypotheses. The results indicate that high performing human resource practices have a positive effect on innovativeness. However, the magnitude of specific practices varies significantly.

Keywords: failure management approach, high-performing human resource practice, intellectual capital, public administration innovation, Serbia.

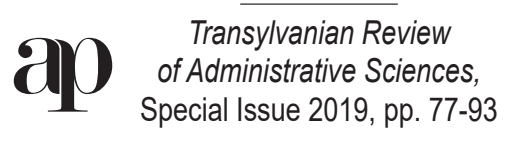




\section{Introduction}

Recently, a broad body of scholarly work has been devoted to the practices of human resource development in public administration (Miao et al., 2017). Human resource practices have been recognized as a paramount antecedent of innovation and intellectual capital creation. Most of the concurrent research in public administration is centered around leadership potential or strategic features of human resources (Manning, 2010). Unfortunately, only a few have attempted to depict and explore the relationship between human resource practices and innovation in public administration.

On the other hand, the notion that the private sector has been overwhelmed with the explanation of the importance of HR development for the creation of intellectual capital is to some extent intriguing. For instance, Kianto, Sáenz and Aramburu (2017) recognize human resource management as a key enabler of intellectual capital and innovation. However, Uslu (2015) finds significant differences in the interaction of HR practices and innovation between public and private sectors. Additionally, organizational behavior theory has pervasively touted failure as a prerequisite for learning and innovations (Mueller and Shepherd, 2016). This failure-innovation interplay, however, is not salient to the private sector only. Nonetheless, this relationship has been out of research radars in the realm of public administration research.

General reasons for this research gap have been vividly discussed in the existing literature (Milosavljević, Milanović and Benković, 2016). For instance, Chow, Xiao and Wen (2018) emphasize that public administration 'has been suffering from three maladies, namely, reductionism, traditionalism, and conservatism, which together reinforce mediocrity'. That being said, the lacuna in the present body of knowledge seeks to be fulfilled.

The aim of this paper is to examine and explore the relationship between high-performing human resource practices and the creation of intellectual capital and consequent innovations in public administration in Serbia. More precisely, the paper aims to explore how human resource practices (training and development, promotion, job security, internal communication and work design) can be used to foster rather than hinder innovation (service, process, organizational and communication innovation), and how bureaucracies as hierarchical structures can overcome the traditional inertial lack of dynamism. Scholars still have limited insight into how human resource development interacts with innovation, let alone public administration. Also, Serbian public administration has been an unexploited field (Milosavljević, Milanović and Benković, 2017). This paper is particularly focused on controlling the previously defined model for failure management practices. In essence, the study will address the impact of tolerance to failure or failure analysis on innovation in public administration.

The remainder of the paper proceeds in the following order. Section 2 examines prior literature and develops the hypotheses. Section 3 depicts the research methodology by explaining variables, measures and research instrument, sampling procedure, and data collection and processing. Section 4 provides an overview of the results. Section 
5 discusses and contextualizes the study findings and explains the main contributions and implications for theory and practice. This section ends with concluding remarks.

\section{Theoretical background}

\subsection{Innovations in public administration}

Innovations could be defined as the improvements of the current state or the creation of new ideas. In the realm of public administration, they have been thoroughly analyzed in the last few decades (Hartley, 2005). A myriad of different typologies has been proposed. In the same study, the term innovation has been distinguished using the following typology: product innovation, service innovation, process innovation, position innovation, strategic innovation, governance innovation and rhetorical innovation. In a systematic review of innovation in the public sector, De Vries, Bekkers and Tummers (2016) collected the recent researches and listed service, organizational, process and communication innovations as the main classes of innovations.

What drives or pushes back innovations in the public sector has been vastly examined in the literature. To name a few - citizen centrism has been advocated to facilitate public services innovation (Cicvarić Kostić et al., 2013). Technology and digitalization play an important role in establishing the necessary infrastructure needed to spur innovation (Scupola and Zanfei, 2016). On the other hand, bureaucratic structure of the public organizations usually slows down the process of organizational learning and change management (Rashman, Withers and Hartley, 2009; Gray, Broadbent and Hartley, 2005; Hartley, 2005; Martin, 2005). Moreover, low tolerance to any potential failures in bringing innovations in the public administration could discourage employees from changing any routine or experimenting with new services, processes or organizational changes (Mazzucato and Semieniuk, 2017).

Bureaucracies are not a fertile ground for innovations. Although innovations can hardly be imposed, the innovation process can be managed. Van de Ven (2017) infers that 'the process of developing innovations from concept to implementation follows a remarkably similar pattern'. Almost anecdotally, the public sector lacks good mechanisms and tools for empowering service, process, organizational or other innovations (Rashman, Withers and Hartley, 2009). An interesting way to boost entrepreneurial spirit, innovation and learning (in the case of the UK) is by converging managers from the public and private sectors (Poole, Mansfield and Gould-Williams, 2006). Nevertheless, a more down-to-earth solution is investment in the development of political appointees and career civil servants to facilitate innovations (Makanyeza, Kwandayi and Ikobe, 2013).

\subsection{High performing human resource practices and innovations}

Human capital has a major role in the overall performance of any organization (Raineri, 2017). The existing literature defines human resources practices (HRP) as the mechanism and set of practices which enhance the motivation and participation of employees, as well as their skills, focusing on better business performance and results. 
Even though there is not an official and agreed set of practices, some of the frequently cited practices include: training and development, performance-linked compensation and promotion (Raineri, 2017), job security (Shanker et al., 2017), as well as work design (Van der Voet and Van de Walle, 2018) and internal communication (Chandani et al., 2016).

Training and development as the determinants of high performing human resource practices are highly related to the performance of an organization. Training has been defined by many authors, showing a strong relationship with organizational performance. Some authors also define it as a systematic approach for improving personal and organizational performance (Punia and Kant, 2013). Nonetheless, training affects innovations and vice versa - the needs for innovation in the public sector require certain investments in employee training and development (Gabriyella, Tobing and Tampubolon, 2018). According to Seidle, Fernandez and Perry (2016), leadership training and development programs in the public sector contribute to raising the efficiency and effectiveness of the public sector. In a study by Ko and Smith-Walter (2013), it was shown that HRM practices have an impact on the organizational commitment, job involvement and organizational citizenship behavior as a cause of an increased organizational performance. Simply put, organizational performance is dependent on the training design and programs for leaders in the public sector. While it was shown that economically developed countries significantly invest in training and development of the public sector, despite various interventions and efforts, emerging countries still achieve poor performance due to the lack of investment in this field (Ozioma Obi-Anike and Ekwe, 2014).

Besides training and development, in emerging and developing countries, recruitment of the top talent represents a big issue (Woo, 2015). Most of the applicants seek job security, fixed working hours and an optimal work-life balance, promotion possibilities and a competitive salary. Due to the change resistance in the public sector, there is an increased need for job security as one of the determinants affecting innovation (Shanker et al., 2017). By analyzing the concept of failing, learning from failures and developing employees, there is a gap between the private and public sectors.

It could be said that job security, promotion and rewards are closely linked to the performance of employees. Employees which have shown to be motivated by promotion, have an increased level of productivity (Nimri, Bdair and Al Bitar, 2015). Also, rewards and promotion are shown to have a significant impact on employee retention, but do not necessarily have an impact on job satisfaction (Terera and Ngirande, 2014). Therefore, promotion as a motivational factor should be treated separately. Promotion as a phenomenon does not have a straightforward relationship with the performance of employees. The Peter Principle states that firms prioritize current job performance in promotion decisions at the expense of other observable characteristics, which can lead to a managerial mismatch (Benson, Li and Shue, 2019).

The infrastructure of public organization services is determined not just by the type of service, but also by work design. Work design is related to how the process- 
es are set, but it also represents an important part of the structural capital, as one of the essential elements of intellectual capital (Bukh, Larsen and Mouritsen, 2001). Managerial work redesign highly affects employee engagement and problem solving (Hernaus, Vujčić and Aleksić, 2017). Nonetheless, the principles of New Public Management have put stress on transformation by analyzing the citizens' needs (Cicvarić Kostic et al., 2013). Citizen (customer) centricity as the intermediate of public administration transformation has provided a new principle for work design. Work design as a tool is also highly associated with the innovations in both corporate and public sector (Gruber et al., 2015). Moreover, process innovation represents a direct output of work design as a tool for shaping organizational processes (Hartley, 2005).

As another dependable variable, internal communication and its strategies are crucial for employee engagement. Employee engagement was shown to have a significant correlation with the innovation of an organization and as a consequence - organizational performance (Chandani et al., 2016). Therefore, internal communications have grown tremendously within both public and corporate sectors. Some authors define internal communications as a strategic tool used in managing the internal flow of information, where employees are seen as a key stakeholder (Tkalac Verčič, Verčič and Sriramesh, 2012). The terms such as 'organizational communication', 'internal marketing' and 'employee communication' also refer to internal communication. Until recently, internal communications have not been the focus of public administration services. Nonetheless, they have become a valuable part of employee engagement and organizational performance as a consequence of internal communications act (Karanges, 2014; Welch, 2011). A transparent and adequate internal communication system is a pre-condition for healthy and growing organizations. Having said that, internal communications will be analyzed as one of the key determinants reviewed above. All of these factors affect the innovativeness of the public sector to some extent. Accordingly, this study hypothesizes that:

H1: High-performing human practices predict innovativeness of public administration.

\subsection{Mediating role of failure management approaches in enhancing the innovation level}

Innovations might be accelerated by investing into human capital, but the process of innovation is often proceeded by trial and error (Borins, 2001). Experimentation contributes significantly to developing new services, processes and driving organizational changes. However, it inevitably carries the risk of failure. In a corporate setting, failure is important for the utilization of opportunities (Mueller and Shepherd, 2016). In public administration, though, failure is often unacceptable as it could be treated as a sign of incompetence (Mazzucato and Semieniuk, 2017). Also, media or opposition criticism pushes public administration to risk-aversion and unwillingness to make changes.

Risk of failure is not a focal point of this paper. On the other hand, approaches to failure (failure management practices) are. A recent study, Milanović, Milosavljević 
and Milošević (2019) has shown that failure management approaches can affect the quality of services in public administration. Failure in innovations can expand the organizational learning and establish the valuable know-how for organizations (Bedenk and Mieg, 2018).

Failure is an omnipresent risk whenever an organization tries to innovate or improve activities. How to best utilize failure remains an open puzzle. Danneels (2008) states that organizations benefit from failure either by analyzing the mistakes or simply by tolerating them. The analysis of failure is a simple and self-evident approach. The succeeding one is more complex. Townsend (2010) points out that creating a failure tolerant environment empowers creativity and innovations. Following the aforementioned, the study hypothesizes that:

H2: Failure tolerance mediates the effects of high-performing human resource practices on the innovativeness of public administration, and

H3: Failure analysis mediates the effects of high-performing human resource practices on the innovativeness of public administration.

\section{Methods}

The study was based on primary data collected in February and March 2019. Data was collected using a structured questionnaire. Two forms of questionnaire were simultaneously used. The primary was an electronic questionnaire, based on CAWI (computer assisted web interviewing). The secondary was a hard-copy form, based on the PAPI-based technique (paper-and-pencil interviewing). While developing the forms of the questionnaire, the authors were led not by the conceptual upsides and flaws for different techniques, but rather by pragmatism. Namely, various governmental institutions and organizations in Serbia prohibit electronic communication (i.e., ministry of internal affairs, central revenue service, etc.).

\subsection{Variables and measures}

The variables and measures used in the questionnaire were developed to best fit the aim of the study. Specifically, the questionnaire had four sections. Following the funnel technique, the first section of the questionnaire was aimed at collecting demographic features of examinees.

The second section of the questionnaire captured the independent variables - advanced human resource development practices in the public sector. For this purpose, the study reworded the operationalization of Mostafa, Gould-Williams and Bottomley (2015). This section consisted of five parts: (1) training and development, (2) job security, (3) work design, (4) internal communication, and (5) promotion. Each part had four inquires measured by a Likert-type scale, ranging from 1 (absolutely disagree) to 7 (absolutely agree).

The third part operationalized the control variable in the study - failure management approaches. The second section was focused on the examination of tolerance for failure perception. The study used the existing measure developed by Danneels (2008). 
The third section focused on the analysis of failure within central government administration. The operative scale was rewarded from Danneels and Vestal (2018) following previously built theoretical constructs (Thomke, 2007). All the items were measured on a Likert-type scale, ranging from 1 (absolutely disagree) to 7 (absolutely agree).

Finally, the fourth part of the questionnaire aimed to collect responses for the dependent variable - innovativeness of a particular public sector entity. Measuring public sector innovation is a conundrum with a myriad of different ways to operationalize this phenomenon. Kobylińska (2016) overviewed six ways in which public sector innovativeness has been measured in EU only (such as CCIC, MEPIN Project, Innobarometer, European Sector Innovation Scoreboard, OECD Observatory of Public Sector Innovation and Inno Policy Trend Chart). For the purpose of this study, a subjective-based measurement scale developed by Bloch and Bugge (2013) was used. This scale uses the inquiries from the 'MEPIN Project', but refines them to best fit the public sector. The scale incorporates four dimensions - product (service) innovation, process innovation, organizational innovation and communication innovation (as opposed to the market innovation in the private sector counterpart). All the items were measured on a Likerttype scale, ranging from 1 (absolutely disagree) to 7 (absolutely agree).

\subsection{Sampling procedure and sample features}

The aim of the study was to examine political appointees and civil servants in central government agencies in Serbia. According to the Statistical Office of the Republic of Serbia (2018), the central government had more than 130,000 employees. Since the central register of email addresses or post office boxes in Serbia is unknown (at least not to the authors of the study), a 'snowball sampling' technique was used. This technique is widely used in public administration studies (i.e., Milanović, Milosavljević and Milošević, 2019).

The snowball sampling technique relies on peer-to-peer recruitment and the formation of referral chain. The initial group was formed from the participants of a master study program at the University of Belgrade. In total, 28 representatives (employed in nine Serbian central government institutions) formed the initial 'block', and created the list of referrals. The lists of potential respondents included their coworkers (both political appointees and career civil servants) from previously defined nine institutions of central administration (most of the institutions were Serbian ministries). Afterwards, they have forwarded the questionnaire. Using the coded questionnaires, the number of referrals was controlled to limit the invasive sub-clustering within the observed units of the central government.

The questionnaire was sent to a total of 963 political appointees and career civil servants. Valid responses were received from 618 examinees, resulting in a response rate of $64.17 \%$. The gender split was uneven $-64.56 \%$ were female. However, this imbalance maps the proportion of women employed in public administration. The average age of examinees was 41.94 years (minimum 23, maximum 65). Sub-clustering was limited to a maximum of $10 \%$. 


\subsection{Data collection and processing}

After the data was collected in both electronic and hard-copy forms in March 2019, the data was entered in the Statistical Package for Social Science software (SPSS v.20). The pre-analysis was done with descriptive statistics (means, standard deviations) and internal reliability tests (Cronbach's Alpha). Interdependence of variables was tested with correlations (Pearson moment two-tailed correlation coefficient analysis). The main analysis and hypotheses testing were conducted by a series of multiple regressions. A hierarchical multiple regression analysis was conducted to control two additional variables.

\section{Results and analysis}

\subsection{Pre-analysis}

Before the hypotheses of the study were tested, a number of pre-analyses were conducted. First, since all the variables were multi-itemed, internal reliability was examined. For this purpose, Cronbach's Alpha was analyzed. The confidence intervals went from 0.79 to 0.94 (Table 1), which was within the recommended thresholds, particularly for social science research (see Bonett and Wright, 2015). High internal consistency reliability was expected having in mind that the majority of multi-itemed variable constructs were reworded from the other scales.

Second, the descriptive statistics were examined. Table 1 shows the means and standard deviations for the observed variables. The results show that the examinees have graded relatively poorly training and development that they received in their organizational units. This does not come with a surprise, at least for two reasons. First, Serbian public administration has only recently established an entity (National Academy for Public Administration) which aims to control and supervise the system of professional development in public administration. However, this entity still does not function at full capacity. Although training and development received the lowest value for the mean $(\overline{\mathrm{x}}=4.24)$, this variable had a relatively high dispersion $(\mathrm{SD}=1.71)$. This could imply that not all of the employees have been dissatisfied with the training and development they received in public administration. Promotion and internal communication had somewhat better results, but they still had means lower than 5 (on a Likert-type scale ranging from 1 to 7 ).

On the other hand, work design and job security were highly ranked. As for the work design $(\overline{\mathrm{x}}=5.34)$, this variable had been market as the paramount factor of the high-performing human practices. This probably means that employees in central public administration appreciate flexibility and conditions in which they work. Similar to work design, job security has been highly graded. This does not come with a surprise, having in mind the fact that public sector jobs have traditionally been considered safe and secure.

As displayed in Table 1, the study has found a number of positive correlations between the observed variables. In particular, moderate correlation was found between 
Table 1: Descriptive statistics, internal reliability and correlation matrix

\begin{tabular}{llllllllllll}
\hline \multicolumn{1}{c}{ Item } & M & SD & CA & $\mathbf{1}$ & $\mathbf{2}$ & $\mathbf{3}$ & $\mathbf{4}$ & $\mathbf{5}$ & $\mathbf{6}$ & $\mathbf{7}$ & $\mathbf{8}$ \\
\hline Training \& Development & 4.24 & 1.71 & 0.94 & & & & & & & \\
Promotion & 4.65 & 1.44 & 0.82 & 0.430 & & & & & & \\
Job Security & 5.08 & 1.35 & 0.86 & 0.574 & 0.358 & & & & & \\
Internal Communication & 4.74 & 1.57 & 0.91 & 0.499 & 0.310 & 0.518 & & & & \\
Work Design & 5.34 & 1.30 & 0.86 & 0.496 & 0.279 & 0.598 & 0.556 & & & \\
Service Innovation & 5.59 & 1.28 & 0.90 & 0.139 & 0.151 & 0.204 & 0.163 & 0.339 & & \\
Process Innovation & 4.58 & 1.45 & 0.90 & 0.275 & 0.182 & 0.293 & 0.275 & 0.309 & 0.558 & \\
Organizational Innovation & 4.37 & 1.75 & 0.93 & 0.455 & 0.278 & 0.457 & 0.399 & 0.399 & 0.358 & 0.538 \\
Communication Innovation & 5.06 & 1.43 & 0.79 & 0.414 & 0.319 & 0.441 & 0.349 & 0.437 & 0.439 & 0.487 & 0.649 \\
\hline (a) M=Mean; SD=Standard Deviation; CA=Cronbach's Alpha & & & & & & & \\
(b) n=618 (Pearson moment two/tailed correlation) & & & & & & & & \\
(c) All correlations significant at p<0.01 & & & & & & & & & & \\
\hline
\end{tabular}

Source: Authors' work

training and development and organizational innovation $(\mathrm{r}=.455, \mathrm{p}<0.01)$, and communication innovation $(\mathrm{r}=0.414, \mathrm{p}<0.01)$, and between job security and organizational innovation $(\mathrm{r}=0.457, \mathrm{p}<0.01)$, and communication innovation $(\mathrm{r}=0.441, \mathrm{p}<0.01)$. Other relationships were statistically significant, but relatively weak. Even though, training and development was rated poorly, the relationship between training and development and the level of innovativeness should not be neglected.

Since the study has found a statistically significant relationship between some independent variables and tolerance, we have performed an additional test to determine the Variable Inflation Factor (VIF) to estimate for a possible multicollinearity. The values of VIF for training and development, promotion, job security, internal communication and work design were 1.781, 1.263, 1.936, 1.661 and 1.826. All the values of VIF are highly below the rule of thumb of VIF $<10$ (O'Brien, 2007), suggesting that there should not be any concern regarding the multicollinearity.

\subsection{Main analysis - hypotheses testing}

After conducting the pre-analysis, the hypotheses have been tested. For this purpose, four standard multiple regression analyses were conducted. Table 2 shows the results of the regression analyses of high performing human resource practices on public administration innovation. Models 1 to 4 are the base models for independent variables - Service Innovation, Process Innovation, Organizational Innovation and Communication Innovation. Since the Durbin-Watson test was in all four cases between critical values $(1.5<\mathrm{d}<2.5)$, it could be assumed that there is no first order linear autocorrelation in the multiple linear regression data.

These four models are all significant at $\mathrm{p}<0.01\left(\mathrm{R}^{2}=0.122,0.129,0.287\right.$, and 0.278 respectively). Coefficients for Promotion and Work Design were significant and positive for Service Innovation $(\mathrm{p}<0.05$ and $\mathrm{p}<0.00)$. Significant predictors (positive co- 
Table 2: Regression analyses for public administration innovation

\begin{tabular}{|c|c|c|c|c|}
\hline & Model 1 & Model 2 & Model 3 & Model 4 \\
\hline \multicolumn{5}{|l|}{ [Constant] } \\
\hline Training \& Development & -0.066 & 0.085 & $0.211^{* *}$ & $0.138^{* *}$ \\
\hline Promotion & $0.085^{\star}$ & 0.043 & 0.052 & $0.129^{* *}$ \\
\hline Job Security & 0.017 & 0.094 & $0.198^{* *}$ & $0.171^{* *}$ \\
\hline Internal Communication & -0.04 & 0.087 & $0.124^{* *}$ & 0.033 \\
\hline Work Design & $0.359^{* *}$ & $0.150^{* *}$ & $0.092^{*}$ & $0.212^{\star *}$ \\
\hline $\mathbf{R}$ & 0.350 & 0.359 & 0.536 & 0.527 \\
\hline $\mathbf{R}^{2}$ & 0.122 & 0.129 & 0.287 & 0.278 \\
\hline Adjusted $\mathrm{R}^{2}$ & 0.155 & 0.122 & 0.282 & 0.272 \\
\hline Durbin-Watson (d) & 1.850 & 2.002 & 1.918 & 1.942 \\
\hline F test & 17.082 & 18.122 & 49.388 & 47.101 \\
\hline Significance & 0.000 & 0.000 & 0.000 & 0.000 \\
\hline \multicolumn{5}{|c|}{$\begin{array}{l}\text { (a) Models 1-4 dependent variables respectively: Service Innovation, Process Innovation, } \\
\text { Organizational Innovation, Communication Innovation } \\
\text { (b) Only standardized coefficients (betas) are given. } \\
\text { (c) Significance: }{ }^{*} p<0.05 ;{ }^{* *} p<0.01 \text {. }\end{array}$} \\
\hline
\end{tabular}

Source: Authors' work

efficients) for Process Innovation was only Work Design ( $\mathrm{p}<0.01)$. A number of positive and significant predictors were found for Organizational Innovation - Training and Development, Job Security, Internal Communication ( $\mathrm{p}<0.01)$, and Work Design $(\mathrm{p}<0.05)$. Finally, Communication Innovation (innovativeness in external communication) was positively predicted by Training and Development, Promotion, Job Security, and Work Design. Unexpectedly, the only insignificant predictor for Communication Innovation was the quality of Internal Communication. Following these findings, hypothesis 1 has been confirmed - high-performing human resource practices significantly predict innovativeness of public administration.

After confirming H1, the other two hypotheses were tested. Hierarchical multiple regression was used to control for two additional variables - Failure Tolerance and Failure Analysis. Table 3 displays the result for the first control variable. Tolerance to failure only slightly changes the variability of dependent variables (R2 change $=3.4 \%$, $3.7 \%, 0.2 \%$, and $1.8 \%$ respectively). Considering the results presented in Table 3, failure tolerance shows a positive impact on the innovativeness, including service innovation $\left(\mathrm{r}=0.204^{* *}, \mathrm{p}<0.01\right)$, process innovation $\left(\mathrm{r}=0.213^{* *}, \mathrm{p}<0.01\right)$ and communication innovation $\left(\mathrm{r}=0.150^{* *}, \mathrm{p}<0.01\right)$, but excluding organization innovation $(\mathrm{r}=0.037)$ due to no significance. However, Failure Tolerance is a fair predictor of innovativeness, except in the case of organizational innovativeness. Also, the inclusion of a second order predictive variable decreases the effect of Work Design.

Another hierarchical multiple regression was run for Failure Analysis as a control variable. As displayed in Table 4, Failure Analysis is a poor predictor of Service 
Table 3: Hierarchical multiple regression analysis of Failure Tolerance as a control variable

\begin{tabular}{|c|c|c|c|c|}
\hline & Model 1a & Model 2a & Model 3a & Model 4a \\
\hline \multicolumn{5}{|l|}{ [Constant] } \\
\hline Training and Development & -0.089 & 0.061 & $0.207^{* *}$ & $.121^{* *}$ \\
\hline Promotion & 0.044 & 0.000 & 0.045 & $.098^{*}$ \\
\hline Job Security & 0.022 & 0.099 & $.199^{* *}$ & $.175^{\star *}$ \\
\hline Internal Communication & -0.059 & 0.067 & $.121^{* *}$ & 0.019 \\
\hline Work Design & $0.319^{* *}$ & $0.108^{*}$ & 0.085 & $.182^{* *}$ \\
\hline Failure Tolerance & $0.204^{* *}$ & $0.213^{* *}$ & 0.037 & $.150^{* *}$ \\
\hline $\mathbf{R}$ & 0.385 & 0.407 & 0.537 & 0.544 \\
\hline $\mathbf{R}^{2}$ & 0.156 & 0.166 & 0.289 & 0.296 \\
\hline $\mathrm{R}^{2}$ Change & 0.034 & 0.037 & 0.002 & 0.018 \\
\hline Adjusted $\mathrm{R}^{2}$ & 0.148 & 0.157 & 0.282 & 0.289 \\
\hline Durbin-Watson (d) & 1.891 & 2.027 & 1.921 & 1.957 \\
\hline F test & 18.798 & 20.197 & 41.309 & 42.826 \\
\hline Significance & 0.000 & 0.000 & 0.000 & 0.000 \\
\hline
\end{tabular}

Source: Authors' work

Innovation and Process Innovation, but rather significantly predicts Organizational Innovation and Communication Innovations (Beta=0.209 and 0.108).

Table 4: Hierarchical multiple regression analysis of Failure Analysis as a control variable

\begin{tabular}{lcccc}
\hline & Model 1b & Model 2b & Model 3b & Model 4b \\
\hline [Constant] & & & & \\
Training and Development & -0.079 & 0.063 & $.174^{* *}$ & $.107^{*}$ \\
Promotion & 0.082 & 0.038 & 0.044 & $.122^{* *}$ \\
Job Security & -0.009 & 0.051 & $.125^{*}$ & $.108^{*}$ \\
Internal Communication & -0.047 & 0.075 & $.104^{*}$ & 0.016 \\
Work Design & $0.342^{\star *}$ & $.122^{*}$ & 0.044 & $.170^{* *}$ \\
Failure Analysis & 0.076 & $.123^{*}$ & $0.209^{* *}$ & $.180^{* *}$ \\
\hline $\mathbf{R}$ & 0.354 & 0.369 & 0.555 & 0.542 \\
$\mathbf{R}^{2}$ & 0.125 & 0.136 & 0.308 & 0.293 \\
$\mathbf{R}^{2}$ Change & 0.003 & 0.007 & 0.021 & 0.015 \\
Adjusted $\mathbf{R}^{2}$ & 0.117 & 0.128 & 0.301 & 0.286 \\
Durbin-Watson (d)W & 1.851 & 1.999 & 1.935 & 1.975 \\
F test & 14.571 & 16.042 & 45.375 & 42.254 \\
Significance & 0.000 & 0.000 & 0.000 & 0.000 \\
\hline
\end{tabular}

Source: Authors' work

In a nutshell, the examinees have acknowledged that their organizational units foster the failure as a learning tool through failure tolerance and analysis, which is inevitable for boosting the level of innovativeness within the public administration. 


\section{Discussion and conclusion}

\subsection{Key findings}

The overall aim of this paper was to examine the influence of high-performing human resource practices (training and development, promotion, job security, internal communication and work design) on public administration innovation (service, process, organizational and communication innovation). The additional aim was to control the effects of failure management practices in public administration, namely failure tolerance and failure analysis approaches. The study collected data from 618 political appointees and career civil servants from central government bodies in Serbia.

The results suggest that high-performing human resource practices are solid predictors of service, process, organizational and communicational innovativeness in public administration. However, building human capital has the least effects when it comes to improving and innovating services in public administration, as only $12.2 \%$ of variability was found. The possible explanation is that services require inclusion of external relationships, collaboration, and co-creation (Merickova, Nemec and Svidronova, 2015), rather than a sole focus on internal capacities (Gonzalez, Llopis and Gasco, 2013). Additionally, human resource practices require time for 'the bureaucratic culture to achieve an agile, responsive government' (OECD, 2015).

The study results portray the way in which particular human resource practices affect different aspects of innovations in public administration. Interestingly, the study does not confirm a statistically significant effect for all hypothesized variables. Surprisingly, for instance, Training and Development does not affect process innovations. It could be speculated that most process adjustments are done because it is a mandatory condition for accessing EU. Another interesting finding is that improvements in Internal Communication do not lead to innovations with regards to external, citizen related communication (for a similar finding in the public sector see Johnson and Chang, 2000).

The results confirm that work design plays a pivotal role in innovativeness. Work design is a multifaceted phenomenon. A number of studies follow the same line of reasoning when it comes to the positive effects of work design (or specific elements of work design) on innovativeness in the public sector. For instance, Van der Voet and Van de Walle (2018 found that two aspects of autonomy in public administration are particularly important - managerial autonomy and lack of political interference. As for the flexibility in public administration, Tuan (2018) finds its overall positive influence on motivation and knowledge sharing. Following the same line of reasoning, the findings of this paper support the importance of flexibility on innovativeness. The results also pinpoint that when controlled for different mechanisms of failure management, work design remains an open puzzle that needs to be solved in order to boost innovativeness in public administration. 


\subsection{Contributions and implications}

The main contributions of the paper are two-fold. First, the study adds to the understanding of the innovation process in public administration. More precisely, the study puts a spotlight on the relationship of high-performing human resource practices and public administration innovation. The findings indicate that changing work engagement through work design and redesign in public administration can boost innovativeness (similar to Hernaus, Vujčić and Aleksić, 2017). While this practice has already been examined in the literature, this study puts a special emphasis on the importance of failure management in public administration. Second, the study puts a spotlight on the understanding of public administration in a country in the EU pre-accession phase.

The practical implication of the results is that policy-holders and decision makers need to actively manage human capital within public administration to obtain a reasonable level of innovativeness. Furthermore, the study emphasizes the importance of creating intellectual capital in the public administration, a phenomenon located high on the agenda of private sector organizations. To facilitate the relationship between high-performing human resource practices and innovation performance, policy-holders should take into account the importance of failure approaches.

\subsection{Limitations and further recommendations}

This study is exposed to a number of challenges. First, a fundamental flaw of the paper is a parsimony of factors included as predictors or mediators of innovativeness. The most obvious mediator, for instance, must have been the motivation of public administration employees. All the independent variables would affect motivation, and motivation could have been one of the most active performance indicators for any organization's innovativeness.

Second, the study scrutinizes the effects of human resource development on innovation, but measures them in a subjective rather than objective way. Further research should be focused on developing a research instrument for measuring both independent and dependent variables in a more profound and objective modus operandi.

Third, this study is quantitative by nature. Other studies should elaborate on specific case studies and take a qualitative perspective on innovativeness in public administration. For instance, politics and the personal aspirations of the politicians de facto influence the innovation process in the public sector (De Vries, Bekkers and Tummers, 2016). This might be an area for future research.

Fourth, a number of interrogatives are attributable to the generalizability of the study findings. The study is highly context-driven in terms of a specific public administration - it examines the case of Serbian central government institutions and organizations. This, in turn, opens an avenue for further studies in other countries and regions. Comparative studies across the continent would be especially beneficial. 


\section{Concluding remarks}

This study provides an overview of the new human resources practices and failure management approaches in the public sector of Serbia. The first results indicated that the high-performing human resources predict the level of innovativeness of the public sector institutions. However, not all of the resources have shown to have a significant impact on all independent variables. From the standpoint of public institutions, this study helps in determining the importance of each of the high-performing human resource practices. By analyzing the failure management approaches, including failure tolerance and failure analysis, it could be said that public services still remain frozen for organizational learning, aiming for the increased level of innovativeness. Nonetheless, positive trends and aspects of innovations could be seen in the public sector of Serbia.

It is hard to have a partial approach to analyze the separate resources, rather than the human practices as a whole; therefore, this study took a holistic approach as the appropriate one. Moreover, including additional aspects of human capital and human resource practices is recommendable for future research.

\section{Acknowledgement}

We thank the anonymous reviewer(s) for their useful suggestions and highly beneficial comments.

\section{References:}

1. Bedenk, S. and Mieg, H.A., 'Failure in Innovation Decision Making', in Kunert, S. (ed.), Strategies in Failure Management: Scientific Insights, Case Studies and Tools, Heidelberg: Springer, 2018, pp. 95-106.

2. Benson, A., Li, D. and Shue, K., 'Promotions and the Peter Principle', 2019, The Quarterly fournal of Economics, vol. 134, no. 4, pp. 2085-2134.

3. Bloch, C. and Bugge, M.M., 'Public Sector Innovation - From Theory to Measurement', 2013, Structural Change and Economic Dynamics, vol. 27, pp. 133-145.

4. Bonett, D.G. and Wright, T.A., 'Cronbach's Alpha Reliability: Interval Estimation, Hypothesis Testing, and Sample Size Planning', 2015, Journal of Organizational Behavior, vol. 36, no. 1, pp. 3-15.

5. Borins, S., 'Encouraging Innovation in the Public Sector', 2001, fournal of Intellectual Capital, vol. 2, no. 3, pp. 310-319.

6. Bukh, P.N., Larsen, H.T. and Mouritsen, J., 'Constructing Intellectual Capital Statements', 2001, Scandinavian fournal of Management, vol. 17, no. 1, pp. 87-108.

7. Chandani, A., Mehta, M., Mall, A. and Khokhar, V., 'Employee Engagement: A Review Paper on Factors Affecting Employee Engagement Employee Engagement', 2016, Indian fournal of Science and Technology, vol. 9, no. 15, DOI: 10.17485/ijst/2016/v9i15/92145.

8. Chow, K.W., Xiao, H. and Wen, M., 'The Maladies of Chinese Public Administration', 2018, Transylvanian Review of Administrative Sciences, vol. 55E, pp. 18-31.

9. Cicvarić Kostić, S., Okanović, M., Milosavljević, M. and Vukmirović, J., 'Antecedents of Citizens' Satisfaction with Local Administration in Serbia', 2013, Transylvanian Review of Administrative Sciences, vol. 40E, pp. 22-34. 
10. Danneels, E. and Vestal, A., 'Normalizing vs. Analyzing: Drawing the Lessons from Failure to Enhance Firm Innovativeness', 2018, fournal of Business Venturing, DOI:10.1016/j. jbusvent.2018.10.001.

11. Danneels, E., 'Organizational Antecedents of Second-order Competences', 2008, Strategic Management fournal, vol. 29, no. 5, pp. 519-543.

12. De Vries, H., Bekkers, V. and Tummers, L., 'Innovation in the Public Sector: A Systematic Review and Future Research Agenda', 2016, Public Administration, vol. 94, no. 1, pp. 146-166.

13. Gabriyella, S.L., Tobing, S.J. and Tampubolon, E., 'Influence of Training and Developing Human Resources to Effectiveness Performance of Employees', 2008, Fundamental Management fournal, vol. 3, pp. 66-74.

14. Gonzalez, R., Llopis, J. and Gasco, J., 'Innovation in Public Services: The Case of Spanish Local Government', 2013, Journal of Business Research, vol. 66, no. 10, pp. 2024-2033.

15. Gray, A., Broadbent, J. and Hartley, J., 'The State of Public Management-Improvement and Innovation', 2005, Public Money and Management, vol. 25, no. 1, pp. 7-8.

16. Gruber, M., de Leon, N., George, G. and Thompson, P., 'Managing by Design', 2015, Academy of Management fournal, vol. 58, no. 1, pp. 1-7.

17. Hartley, J., 'Innovation in Governance and Public Services: Past and Present', 2005, Public Money and Management, vol. 25, no. 1, pp. 27-34.

18. Hernaus, T., Vujčić, M.T. and Aleksić, A., 'Changing Work Engagement: The Longitudinal Effect of a Job Redesign Intervention among Public Sector Employees’, 2017, Strategic Management, vol. 22, no. 2, pp. 3-8.

19. Johnson, J.D. and Chang, H.J., 'Internal and External Communication, Boundary Spanning, and Innovation Adoption: An Over-Time Comparison of Three Explanations of Internal and External Innovation Communication in a New Organizational Form', 2000, The fournal of Business Communication, vol. 37, no. 3, pp. 238-263.

20. Karanges, E.R., 'Optimizing Employee Engagement with Internal Communication: A Social Exchange Perspective', 2014, Journal of Business Marketing Management, vol. 7, no. 2, pp. 329-353.

21. Kianto, A., Sáenz, J. and Aramburu, N., 'Knowledge-based Human Resource Management Practices, Intellectual Capital and Innovation', 2017, Journal of Business Research, vol. 81, pp. 11-20.

22. Ko, J. and Smith-Walter, A., 'The Relationship Between HRM Practices and Organizational Performance in The Public Sector: Focusing on Mediating Roles of Work Attitudes', 2013, International Review of Public Administration, vol. 18, no. 3, pp. 209-231.

23. Kobylińska, U., 'Public Sector Innovativeness in Poland and in Spain - Comparative Analysis', 2016, International fournal of Contemporary Management, vol. 14, no. 2, pp. 7-22.

24. Makanyeza, C., Kwandayi, H.P. and Ikobe, B.N., 'Strategies to Improve Service Delivery in Local Authorities', 2013, International Journal of Information Technology and Business Management, vol. 15, no. 1, pp. 1-11.

25. Manning, K., 'Strategic Human Resource Management and the Australian Public Sector', 2010, Transylvanian Review of Administrative Sciences, vol. 30E, pp. 150-161.

26. Martin, S.J., 'Public Service Improvement: Current Developments and Future Research Agendas', 2005, Local Government Studies, vol. 31, no. 5, pp. 531-540.

27. Mazzucato, M. and Semieniuk, G., 'Public Financing of Innovation: New Questions', 2017, Oxford Review of Economic Policy, vol. 33, no. 1, pp. 24-48. 
28. Merickova, B.M., Nemec, J. and Svidronova, M., 'Co-Creation in Local Public Services Delivery Innovation: Slovak Experience’, 2015, Lex Localis - Journal for Local-Self Government, vol. 13, no. 3, pp. 521-535.

29. Miao, Q., Newman, A., Schwarz, G. and Cooper, B. 'How Leadership and Public Service Motivation Enhance Innovative Behavior', 2017, Public Administration Review, vol. 78, no. 1, pp. 71-81.

30. Milanović, N., Milosavljević, M. and Milošević, N., 'Failure Management Approaches and Public Service Quality: Empirical Evidence from Serbia', 2019, Lex Localis - Fournal for Local-Self Government, vol. 19, no. 3, DOI:10.4335/17.3.417-433(2019)

31. Milosavljević, M., Milanović, N. and Benković, S., 'Politics, Policies and Public Procurement Efficiency: A Quantitative Study of 25 European Countries', 2016, Lex Localis - fournal of Local Self-Government, vol. 14, no. 3, pp. 537-558.

32. Milosavljević, M., Milanović, N. and Benković, S., 'Waiting for Godot: Testing Transparency, Responsiveness and Interactivity of Serbian Local Governments', 2017, Lex Localis - Journal of Local Self-Government, vol. 15, no. 3, pp. 513-528.

33. Mostafa, A.M.S., Gould-Williams, J.S. and Bottomley, P., 'High-performance Human Resource Practices and Employee Outcomes: The Mediating Role of Public Service Motivation', 2015, Public Administration Review, vol. 75, no. 5, pp. 747-757.

34. Mueller, B.A. and Shepherd, D.A., 'Making the Most of Failure Experiences: Exploring the Relationship between Business Failure and the Identification of Business Opportunities', 2016, Entrepreneurship Theory and Practice, vol. 40, no. 3, pp. 457-487.

35. Nimri, M., Bdair, A. and Al Bitar, H., 'Applying the Expectancy Theory to Explain the Motivation of Public Sector Employees in Jordan', 2015, Middle East fournal of Business, vol. 10, no. 3, pp. 70-82.

36. OECD, 'Achieving Public Sector Agility at Times of Fiscal Consolidations', OECD Public Governance Reviews, 2015, [Online] available at https:/www.oecd.org/publications/ achieving-public-sector-agility-at-times-of-fiscal-consolidation-9789264206267-en.htm, accessed on January 29, 2019.

37. Ozioma Obi-Anike, H. and Ekwe, M.C., 'Impact of Training and Development on Organizational Effectiveness: Evidence from Selected Public Sector Organizations in Nigeria', 2014, European fournal of Business and Management, vol. 6, no. 29, vol. 66-75.

38. Poole, M., Mansfield, R. and Gould-Williams, J., 'Public and Private Sector Managers Over 20 Years: A Test of the 'Convergence Thesis', 2006, Public Administration, vol. 84, no. 4, pp. 1051-1076.

39. Punia, B.K. and Kant, S., 'A Review of Factors Affecting Training Effectiveness vis-a-vis Managerial Implications and Future Research Directions', 2013, International fournal of Advanced Research in Management and Social Sciences, vol. 2, no. 1, pp. 151-164.

40. Raineri, A., 'Linking Human Resources Practices with Performance: The Simultaneous Mediation of Collective Affective Commitment and Human Capital', 2017, The International Journal of Human Resource Management, vol. 28, no. 22, pp. 3149-3178.

41. Rashman, L., Withers, E. and Hartley, J., 'Organizational Learning and Knowledge in Public Service Organizations: A Systematic Review of the Literature', 2009, International fournal of Management Reviews, vol. 11, no. 4, pp. 463-494.

42. Scupola, A. and Zanfei, A., 'Governance and Innovation in Public Sector Services: The Case of the Digital Library’, 2016, Government Information Quarterly, vol. 33, no. 2, pp. 237-249. 
43. Seidle, B., Fernandez, S. and Perry, J.L., 'Do Leadership Training and Development Make a Difference in the Public Sector? A Panel Study', 2016, Public Administration Review, vol. 76, no. 4, pp. 603-613.

44. Shanker, R., Bhanugopan, R., Van der Heijden, B.I. and Farrell, M., 'Organizational Climate for Innovation and Organizational Performance: The Mediating Effect of Innovative Work Behavior', 2017, fournal of Vocational Behavior, vol. 100, pp. 67-77.

45. Statistical Office of the Republic of Serbia, 'Statistika zaposlenosti i rada', 2018, [Online] available at http://publikacije.stat.gov.rs/G2018/Pdf/G20181293.pdf, accessed on January 23, 2019.

46. Terera, S.R. and Ngirande, H., 'The Impact of Rewards on Job Satisfaction and Employee Retention', 2014, Mediterranean fournal of Social Sciences, vol. 5, no. 1, pp. 481-487.

47. Thomke, S., 'Learning from Projects: Note on Conducting A Postmortem Analysis', New York, 2007.

48. Tkalac Verčič, A., Verčič, D. and Sriramesh, K., 'Internal Communication: Definition, Parameters, and the Future', 2012, Public Relations Review, vol. 38, no. 2, pp. 223-230.

49. Townsend, W., 'Innovation and the Value of Failure', 2010, International fournal of Management \& Marketing Research (IFMMR), vol. 3, no. 1, pp. 75-84.

50. Tuan, L.T., 'Behind the Influence of Job Crafting on Citizen Value Co-Creation with The Public Organization: Joint Effects of Paternalistic Leadership and Public Service Motivation', 2018, Public Management Review, vol. 20, no. 10, pp. 1533-1561.

51. Uslu, T., 'Innovation Culture and Strategic Human Resource Management in Public and Private Sector within the Framework of Employee Ownership', 2015, Procedia - Social and Behavioral Sciences, vol. 195, pp. 1463-1470.

52. Van de Ven, A.H., 'The Innovation Journey: You Can't Control It, But You Can Learn to Maneuver It', 2017, Innovation, vol. 19, no. 1, pp. 39-42.

53. Van der Voet, J. and Van de Walle, S., 'How Cutbacks and Job Satisfaction Are Related: The Role of Top-Level Public Managers' Autonomy', 2018, Review of Public Personnel Administration, vol. 38, no. 1, pp. 5-23.

54. Welch, M., 'The Evolution of The Employee Engagement Concept: Communication Implications', 2011, Corporate Communications: An International fournal, vol. 16, no. 4, pp. 328-346.

55. Woo, K.H., 'Recruitment Practices in the Malaysian Public Sector: Innovations or Political Responses?', 2015, Journal of Public Affairs Education, vol. 21, no. 2, pp. 229-246. 